Amirullah Abduh, Rosmaladewi Ros

maladewi, Muhammad Basri

Indonesia

\title{
Internationalization Awareness and Commitment of Indonesian Higher Education
}

DOI: 10.15804/tner.2018.51.1.13

\begin{abstract}
This paper aims to explore internationalization awareness and commitment of higher education in Indonesia. Since there are no publications on internationalization awareness and commitment for Indonesian higher education, this paper fills this gap. This qualitative case study involved 15 lecturers from an Indonesian university. This study used semi-structured interviews and data from the interviews were analyzed thematically. The research findings reveal that the internationalization of curriculum indicates awareness of internationalization by inviting experts and adapting curricula from developed countries. In addition, the commitment of internationalization was marked by the increasing quantity of international publications and collaboration with domestic and global agencies. The internationalization process faces both cultural and practical constraints. The finding suggests that there should be more elements of internationalization to indicate the preparation and the implementation of internationalization.
\end{abstract}

Keywords: internationalisation, awareness, commitment, higher education, Indonesia 


\section{Introduction}

Internationalization of higher education has been the focus of many developing countries, including Indonesia. Internationalization of universities in Indonesia has concentrated on all aspects of academic life including curriculum, teaching methods, lecturers exchange, educational facilities, the use of English as a medium of instruction, and international partnership with other universities overseas. These changes cause a large number of problems within Indonesian higher education institutions such as the need to increase English competences for lecturers who teach in international programs, the need to provide facilities to support internationalization, lack of interrelated goals among different academic sections, and limited supporting staff for internationalization of higher education. For these reasons, it is essential to further explore the internationalization of higher education within this context.

The Indonesian higher education strategic planning aims to compete at the regional level by 2015 and at the international level by 2020. Since there are not many publications on the internationalization of universities in Indonesia, this paper will explore the internationalization process of Indonesian higher education using Knight's (2003) model. This article is significant concerning the identification of internationalization awareness and commitment of an Indonesian university to achieve world standards.

\section{Literature review}

\section{Concept of internationalization awareness and commitment}

Internationalisation has been applied in different countries such as internationalization in South Korean higher education (Park, Kim, \& DeMatteo, 2016) and Canadian higher education (Qiang, 2003). The internationalization of higher education is seen as a continuous cycle rather than a static and linear process. The internationalization cycle includes awareness and commitment. The concept of the awareness and commitment of internationalization of higher education (Knight, 2003; Morosini, Corte, \& Guilherme, 2017; Park et al., 2016) is applied in this paper (Table 1).

To facilitate the implementation of internationalization elements, higher education institutions need to understand these aspects, which fall within the remit of their current capacity and topical knowledge. They also need to have sufficient resources and facilities to support internationalization to indicate their readiness and 
Table 1. Adapted concept of internationalization awareness and commitment

\begin{tabular}{ll}
\hline Key elements & \multicolumn{1}{c}{ Explanations } \\
\hline Awareness & $\begin{array}{l}\text { The overarching needs, purpose, rationale, strategies, curriculum, resources, } \\
\text { analysis of implications and benefits for internationalization have to be under- } \\
\text { stood by all higher stakeholders. The prevalent attitudes and perceptions of } \\
\text { the motivations of internationalization can become driving factors to achieve } \\
\text { shared commitments. }\end{array}$ \\
\hline Commitment & $\begin{array}{l}\text { The dedication and efforts of government, senior management, lecturers, staff, } \\
\text { and students are internal stakeholders of the university that integrate into } \\
\text { teaching and learning the culture, research and community services. }\end{array}$ \\
\hline
\end{tabular}

preparation to face internationalization. Conceptually, these internationalization elements are starting points for innovative ways to move internationalization beyond activity oriented. These features can become parameters to explore and measure the fluidity and mobility of higher education in providing a better quality and meaningful education.

\section{Previous studies on awareness and commitment to internationalization of higher education}

Despite there being a large number of studies of the internationalization of higher education, only several researchers concentrate on the internationalization process of higher education (Henard, Diamond, \& Roseveare, 2012; Knight, 2003; Morosini et al., 2017; Wit, 2011).

First, Henard et al. (2012) investigated the collaborative work between government and universities to overcome challenges in the internationalization of higher education. Using online focus group discussions, 16 participants in the research were practitioners, researchers, volunteers, and non-government organization members from developed countries. The findings of the study included factors, challenges, and strategies to promote the internationalization of higher education. The research shows that the strategies they identified are applicable to higher education in non-developed countries. In addition, the research also suggests that the government should play a significant role in the internationalization of higher education.

Second, Knight (2003) conducted an online survey of 610 academics across the globe. The investigation uncovers practices and priorities of the internationaliza- 
tion of higher education in Asia, Africa, America, and Europe. The findings show that a) mobility of students and lecturers is a crucial factor in internationalization; b) the loss of local identity becomes the challenge of internationalisation; c) international collaboration among academics has to be promoted in internationalization; d) funding is the second critical factor in internationalization; e) regional partnership has to be established prior to worldwide partnership; f) quality assurance has to be put in place in order to guarantee the process of internationalization. The finding also indicates that among various regions, Europe is the most prepared region to face internationalization.

Third, Wit (2011) explored the misconceptions of internationalization. Wit reviewed the database of journals and resources that discuss internationalization. The findings suggest that internationalization is not a separate approach to each section of higher education, but a more integral process-based approach focusing on a better quality of higher education. Most universities concentrate on an activity-based path which leads to the misconceptions of internationalization. Wit argued that internationalization is a comprehensive approach to a better quality of teaching and students in higher education institutions.

More recent research was conducted by Morosini et al. (2017) in the Brazilian higher education context. The research examined discourses on internationalization written by academics and research students in Brazil. The findings of the study suggest that the discourse of internationalization has been the focus of the debate among young scholars, the main topic of dissertations and theses of postgraduate doctoral and master's degree students, and publications of senior academics. One of the key focuses was mobility to gain greater experience of the process of becoming global citizens. The process of internationalization in Brazil has been recognized as one of the Great Souths.

Even though the above-mentioned studies show positive and convincing evidence regarding the internationalization of higher education, Morosini et al. (2017) argued that there is still the need for exploring internationalization awareness and commitment in another context. So far, no empirical effort has been undertaken focusing on the internationalization awareness and commitment in the Indonesian context to help policymakers and leaders to provide views on the current practice of internationalization. This is important because all universities aim to be internationally recognized. To fill this gap, the presented study attempts to continue the scholarship of the internationalization of higher education. 


\section{Methodology}

\section{Research questions}

1. What are the effective strategies to achieve internationalisation awareness and commitment?

2. What would be the challenges of the internationalisation of higher education?

\section{Research design}

This research applied the case study approach. A case study was an appropriate way to investigate current conditions of the phenomenon being implemented in an educational setting. It allowed the researcher to reveal present circumstances of an issue holistically using different kinds of evidence such as documents, interviews, artifacts and direct observations (Yin, 2013) Specifically, the case study method was appropriate for this study because it offered an overarching strategy to understand, explore and inform policymakers and educational stakeholders related to the implemented program(Gall, Gall, \& Borg, 2007). In this case, the policy was the internationalization of an Indonesian higher education.

\section{Participants and data collection}

Participants were selected based on the following criteria: a) they were currently involved in international class programs; $b$ ) they were teaching in year one, year two and year three; c) they were between the ages of 30 and 60 . The total number of participants from the university was 15 lecturers (Table 2).

Table 2. Participants in the study

\begin{tabular}{llcll}
\hline Participants & Age & Sex & $\begin{array}{c}\text { Educational back- } \\
\text { ground }\end{array}$ & \multicolumn{1}{c}{ Position in a university } \\
\hline Participant 1 & $40 \mathrm{~s}$ & $\mathrm{M}$ & $\mathrm{PhD}$ & Dean \\
\hline Participant 2 & $40 \mathrm{~s}$ & $\mathrm{~F}$ & $\mathrm{PhD}$ & Deputy Dean for Academics \\
\hline Participant 3 & $40 \mathrm{~s}$ & $\mathrm{M}$ & $\mathrm{PhD}$ & Deputy Dean for Administration \\
\hline Participant 4 & $50 \mathrm{~s}$ & $\mathrm{~F}$ & $\mathrm{PhD}$ & Deputy Dean for Students \\
\hline Participant 5 & $50 \mathrm{~s}$ & $\mathrm{M}$ & $\mathrm{PhD}$ & Deputy Dean for Partnership \\
\hline Participant 6 & $30 \mathrm{~s}$ & $\mathrm{~F}$ & $\mathrm{PhD}$ & Head of Department \\
\hline Participant 7 & $40 \mathrm{~s}$ & $\mathrm{M}$ & $\mathrm{PhD}$ & Head of laboratory \\
\hline Participant 8 & $40 \mathrm{~s}$ & $\mathrm{~F}$ & $\mathrm{PhD}$ & Secretary of Department \\
\hline Participant 9 & $40 \mathrm{~s}$ & $\mathrm{M}$ & $\mathrm{PhD}$ & Professor \\
\hline Participant 10 & $40 \mathrm{~s}$ & $\mathrm{~F}$ & $\mathrm{PhD}$ & Associate Professor \\
\hline
\end{tabular}




\begin{tabular}{lccll}
\hline Participants & Age & Sex & $\begin{array}{c}\text { Educational back- } \\
\text { ground }\end{array}$ & \multicolumn{1}{c}{ Position in a university } \\
\hline Participant 11 & $40 \mathrm{~s}$ & $\mathrm{M}$ & Master & Senior lecturer \\
\hline Participant 12 & $50 \mathrm{~s}$ & $\mathrm{~F}$ & Master & Senior lecturer \\
\hline Participant 13 & $30 \mathrm{~s}$ & $\mathrm{M}$ & Master & Lecturer \\
\hline Participant 14 & $30 \mathrm{~s}$ & $\mathrm{M}$ & Master & Lecturer \\
\hline Participant 15 & $30 \mathrm{~s}$ & $\mathrm{M}$ & Master & Lecturer \\
\hline
\end{tabular}

The presented study used semi-structured individual interviews that lasted between 45 minutes and one hour. The interviews followed Patton's suggestion (2002) of creating an informal and convenient atmosphere, even though most of the interviews were conducted in the participants' office rooms; few of them were interviewed outside campus. The interviews began with an easy topic discussing the purpose of the interviews and linking through all the semi-structured questions (cf., Appendix 1) and probing all the relevant information. Arranging time to meet the participants was a slight hurdle. However, the researchers overcame the difficulty meeting with the participants at a time that was convenient for them and visiting them in their offices several times to establish trust and sincerity in conducting the research.

\section{Data analysis}

Thematic analysis was used to code data inductively from different kinds of evidence. Thematic analysis "involves the searching across a data set - be that some interviews or focus groups, or a range of texts - to find repeated patterns of meaning" (Braun and Clarke, 2006, p. 15). Six steps of thematic analysis were adapted from Braun and Clarke (2006): a) reading transcript documents of the interviews; b) performing initial coding; $c$ ) searching for themes; d) reviewing and connecting themes; e) identifying global themes, and f) creating a storyline. This process of data analysis assisted the researchers to locate the participants' quotes appropriately in the findings of this research.

\section{Findings and Discussion}

\section{Awareness of higher education internationalization}

This university shows a strong interest in promoting awareness to be internationally recognized. This university aims to make the institution a World Class University. To achieve this, two important ways were chosen: First, this institution 
internationalized their curricula through some ways: a) inviting experts and educational stakeholders to provide input for the improvement of the curricula and b) adapting the curricula from developed countries. The participants expressed their awareness of internationalizationin as follows:

\begin{tabular}{ll}
\hline Participant 1 & $\begin{array}{l}\text { "We are committed to providing internationalized curricula for the inter- } \\
\text { national class programs. We tend to adapt curricula from the international } \\
\text { standardized agency such as OECD countries. From these, we can learn what } \\
\text { is going on overseas". }\end{array}$ \\
\hline Participant 13 & $\begin{array}{l}\text { "We work together with our partner institutions to internationalize curricula, } \\
\text { and we ask them to examine and verify our curricula so that we can get input } \\
\text { and suggestions from them." }\end{array}$ \\
\hline Participant 3 & $\begin{array}{l}\text { "We invite experts and other educational stakeholders to provide input for } \\
\text { the development of our curricula. The aim is to adjust our curricula to the } \\
\text { demand of the labour market". }\end{array}$ \\
\hline $\begin{array}{l}\text { "The curriculum we have is also verified by internal experts so that the combi- } \\
\text { nation of external and internal experts can provide overarching input for the } \\
\text { improvement of the curricula." }\end{array}$ \\
\hline
\end{tabular}

As seen from the excerpts above, each participant emphasised the importance of internationalizing curricula for different reasons. Participants 13 and 14 chose to provide opportunities for input and suggestion by both internal and external educational stakeholders. This approach helped strengthen the curriculum of international class programs. For Participant 1 , the internationalization of curricula was important for lecturers and students to be aware of the global situation. This approach assisted lecturers and students to be up-to-date with the current development of knowledge and technology. In addition, Participant 3 was concerned about meeting the demand of the labour market, i.e., the curriculum had to be adjusted to the needs of industry. The evidence of the internationalization of curriculum is in line with Knight's idea that "the curriculum is a key thrust of internationalization" (p.16). Providing opportunities for curriculum input certainly raises and increases the internationalization awareness of lecturers, assists them to become globally engaged and, in turn, include self-awareness in the international curriculum.

Second, the awareness of this university was sending their academics and administrative staff to pursue further studies overseas. The participants in this study indicate: 


\begin{tabular}{ll}
\hline Participant 5 & $\begin{array}{l}\text { "We support all academics and [administrative] staff to continue their studies. } \\
\text { They can study at the master's or doctoral levels. The reason is that we want } \\
\text { them to experience living overseas and at the same time to have the opportunity } \\
\text { to publish papers in international journals". }\end{array}$ \\
\hline Participant 6 & "I believe that lecturers can benefit from seeing and experiencing the best prac- \\
& tices of higher education. So when they finish they can adapt and apply it to the \\
Indonesian context".
\end{tabular}

Sending Indonesian lecturers and administrative staff to pursue $\mathrm{Med} / \mathrm{PhD}$ degrees overseas could assist the improvement of the quality of human resources. This approach can enhance the performance of teaching and learning, which lead to a better quality of education. This evidence is in accordance with Knight's (2003) concept of "mobility of lecturers is considered to be the most important reason for making internationalization a priority and is identified as the fastest growing aspect of internationalization" (p. 3). This aspect can be the point of departure for academics to engage in prolonged international activities.

\section{Commitment to higher education internationalization}

Internationalisation became one of the key commitments of this Indonesian university. The policies of internationalization are: a) the establishment of partnership both domestic and overseas; and b) encouraging educators to write and publish in international accredited journals. The participants in the study commented:

\begin{tabular}{ll}
\hline Participant 9 & $\begin{array}{l}\text { "The university is actively involved in collaboration with many domestic } \\
\text { and international institutions. The domestic ones include local governments, } \\
\text { schools and universities, and international agencies include universities, } \\
\text { international donors, private foundations, and research institutions". }\end{array}$ \\
\hline Participant 10 & "Yes, we have different kinds of partnership, for example with universities in \\
& $\begin{array}{l}\text { ASEAN [Association of Southeast Asian Countries]. The partnerships include } \\
\text { joint publications, partnership in community services, and student mobility". }\end{array}$ \\
\hline Participant 11 & "The collaboration with all schools in this province, for example, has helped \\
& us to provide an opportunity for our students to have job training." \\
\hline
\end{tabular}




\begin{tabular}{ll}
\hline Participant 12 & "I am involved directly in the collaboration with universities overseas. We ini- \\
& tiated an international conference together, which was held last month. That's \\
& the evidence of how we build a partnership with universities abroad".
\end{tabular}

These participants feel that they need to develop collaboration because within such an approach they can establish a more academic partnership. This work would be beneficial for lecturers because "academic partnership is something which forms the basis for cooperation and must necessarily lead to a much deeper development" (Morosini et al., 2017, p. 109). As their partnership becomes well established, the participants could collaborate on a joint publication, series of conferences, exchange of lecturers, and community services. This finding indicates that the connection could lead to a long-term professional relationship and academic friendship.

Also, he leaders at this university encourage educators to write and publish in international accredited journals. The participants in the study commented:

\begin{tabular}{ll}
\hline Participant 2 & $\begin{array}{l}\text { "From zero international publication, we have now more than 200 Scopus } \\
\text { publications in international journals. This is important as an indicator of } \\
\text { research activities in this university". }\end{array}$ \\
\hline Participant 4 & $\begin{array}{l}\text { "I think the government has provided the reward for authors whose articles } \\
\text { are published in reputable journals. This message should be passed on to all } \\
\text { lecturers so that they can be motivated to write in international journals". }\end{array}$ \\
\hline Participant 15 & $\begin{array}{l}\text { "We have set up a lot of agreement with our partners overseas. Our lecturers } \\
\text { will have their articles peer reviewed by native English speakers so they will be } \\
\text { readable and understandable". }\end{array}$ \\
\hline
\end{tabular}

Based on the above excerpts, the participants did value international publication because this platform allows them to express, examine, share, and disseminate their thought globally. The participants' voices here show that papers of their research output are the key to fruitful international engagement with the broader academic community. Thus, internationalization is regarded as a process to "upgrade the quality of education and research which remains ad hoc and marginal (Wit, 2011, p. 6). Also, encouraging educators to write and publish in international accredited journals was one of the university's commitments to being internationally recognized for better quality research and education. 


\section{Challenges of internationalization of higher education}

There were two types of challenges: cultural and practical perceptions. Regarding cultural constraints, the main problem, as most participants indicated, was lack of academic and intellectual cultures among academics, students, and staff. For example, Participant 9 commented: "We have to admit that there are limited academic activities such as a series of seminar and workshops that are held regularly among lecturers." Similarly, Participant 14 stated that "it is a challenge for us to create the academic climate since there are not many such activities occurring at the moment." This cultural constraint could become barriers that impede the internationalization of this institution due to limited funds. As a consequence, the lower subsidies for conducting educational seminars and workshops block their engagement with broader academic communities and researchers.

In addition, a practical constraint faced by this university is a lack of English language competence. The mastery of English as a medium of instruction is one of the critical components for the internationalization of higher education (Knight, 2009). Participant 15 commented: "We are improving our English through courses and training in both domestic and overseas programs. Some of us still have a low level of English. We aim at TOEFL score 525 [Test of English as a Foreign Language] for all lecturers teaching at international programs. This competence will enable them to teach contents in English fluently". Additionally, Participant 1 said that "we are committed to providing continuing support for English language learning for lecturers because we still have some lecturers below the target level of English competence." As a consequence, the lack of English competence to support internationalization could lead to poor quality teaching and learning at this institution. This, in turn, could impact on the process of internationalization of this higher education institution.

\section{Conclusion}

Based on the findings, the participants were aware of and committed to supporting the internationalization of higher education through engagement in curriculum development, lecturer mobility, research article publication in reputable journals, and collaboration with both domestic and international agencies. As the lecturers' experiences and involvement in an international class program, this social process shows the value of commitment to the better quality of higher education. Despite cultural and practical challenges, as a whole, the lecturers 
show socially and cognitively meaningful involvement in the internationalization of higher education. The findings of the study are obtained from the experiences of lecturers as practitioners in an international class program in an Indonesian university. Therefore, further work is required on other populations, particularly students' and administrative staff's experiences to gain more comprehensive evidence of the internationalization process and practice. Additionally, longitudinal ethnographic research should be undertaken to reveal the culture of the internationalization of higher education. Case studies are also needed to explore the use of different strategies to support the internationalization of higher education.

\section{References}

Braun, V., \& Clarke, V. (2006). Using thematic analysis in psychology. Qualitative Research in Psychology, 3(2), 77-101.

Gall, M., Gall, J., \& Borg, W. (2007). Educational research: an introduction. Boston: Pearson/ Allyn \& Bacon.

Henard, F., Diamond, L., \& Roseveare, D. (2012). Approaches to Internationalisation and Their Implications for Strategic Management and Institutional Practice. New York: OECD Clearance Center.

Knight, J. (2003). Internationalization of Higher education Practices and Priorities: 2003 IAU Survey Report. Higher Education. Paris: International Association of Universities.

Morosini, M.C., Corte, M.G.D., \& Guilherme, A. (2017). Internationalization of Higher Education: A Perspective from the Great South. Creative Education, 8(1), 95-113. https://doi.org/10.4236/ce.2017.81008

Park, J.K., Kim, Y.D., \& DeMatteo, K. (2016). Nation branding through internationalization of higher education: A case study of African students in South Korea. New Educational Review, 45(3), 52-63. https://doi.org/10.15804/tner.2016.45.3.04

Wit, H.De. (2011). Internationalization of Higher Education: Nine Misconceptions. International Higher Education, (64), 17-19. https://doi.org/10.6017/ihe.2011.64.8556

Yin, R. (2013). Case study research: Design and methods. California: Sage Publications. 